\title{
SOME ANAEROBIC PERFORMANCE VARIATIONS FROM MORNING TO EVENING: MASSAGE AFFECTS PERFORMANCE AND DIURNAL VARIATION
}

\author{
ALGUMAS VARIAÇÕES DE DESEMPENHO ANAERÓBICO DA MANHÃ À NOITE: A \\ MASSAGEM AFETA O DESEMPENHO E A VARIAÇÃO DIURNA
} ALGUNAS VARIACIONES DE RENDIMIENTO ANAERÓBICO DE LA MAÑANA A LA
NOCHE: EL MASAJE AFECTA EL RENDIMIENTO Y LA VARIACIÓN DIURNAL

\author{
Ramazan BAYER ${ }^{1}$ \\ Özgür EKEN ${ }^{2}$
}

\begin{abstract}
This study was conducted to determine the effects of massage on some anaerobic performance and diurnal variation. Twelve male athletes between the ages of 18-25, who exercised regularly for three days a week (age, $18.00 \pm 2.17$ years; height, $168 . \pm 3.15 \mathrm{~cm}$; $65 \pm 2.63 \mathrm{~kg}$; BMI 22.49 \pm .44 years) participated in the study. While the non-massage protocol consisted of only 15 minutes of jogging (NM), the protocol with sports massage consisted of 5 minutes of jogging and 10 minutes of sports massage (SM). The protocols were applied in two time periods of the day (morning: 09.00-11.00, evening: 16.00-18.00). It has been reported that SM positively affects peak power and average power due to vertical jump performance compared to the NM protocol. In addition, it was determined that the SM protocol applied in the evening was more effective than SM protocol applied in the morning.
\end{abstract}

KEYWORDS: Diurnal variation. Sport massage. Vertical jump. Anaerobic power. Mean power.

RESUMO: Este estudo foi realizado para determinar os efeitos da massagem no desempenho anaeróbio e na variação diurna. Doze atletas do sexo masculino com idades entre 18-25 anos, que se exercitavam regularmente três dias por semana (idade, 18,00 $\pm 2,17$ anos; altura, $168,1 \pm 3,15 \mathrm{~cm} ; 65 \pm 2,63 \mathrm{~kg}$; IMC 22,49 $\pm 0,44$ anos) participaram do estudo. Enquanto o protocolo sem massagem consistia em apenas 15 minutos de corrida (NM), o protocolo com massagem esportiva consistia em 5 minutos de corrida e 10 minutos de massagem esportiva (SM). Os protocolos foram aplicados em dois períodos do dia (manhã: $09 \mathrm{~h} 00$ às 11h00, tarde: $16 \mathrm{~h} 00$ às 18h00). Foi relatado que SM afeta positivamente a potência de pico e a potência média devido ao desempenho do salto vertical em comparação com o protocolo NM. Além disso, determinou-se que o protocolo SM aplicado à noite foi mais eficaz do que o protocolo SM aplicado pela manhã.

PALAVRAS-CHAVE: Variação diurna. Massagem esportiva. Salto vertical. Potência anaeróbia. Potência média.

\footnotetext{
${ }^{1}$ Malatya Turgut University (MTÜ), Malatya - Turkey. Dr. Lecturer in Rectorate. Phd in Physical Education and Sport. ORCID: https://orcid.org/0000-0002-2161-5886.E-mail: rmznbayer@gmail.com

2 Inonu University (İNONU), Malatya - Turkey. Dr. Research Assistant in Faculty of Sport Sciences, Department of Physical Education and Sport Teaching. Phd in Physical Education and Sport. ORCID: https://orcid.org/0000-0002-5488-3158. E-mail: ozgureken86@gmail.com
} 
RESUMEN: Este estudio se realizó para determinar los efectos del masaje sobre el rendimiento anaeróbico y la variación diurna. Doce atletas masculinos entre las edades de 18-25, que hacian ejercicio regularmente durante tres días a la semana (edad, 18,00 $\pm 2,17$ años; altura, 168. $\pm 3,15 \mathrm{~cm} ; 65 \pm 2,63 \mathrm{~kg}$; IMC 22,49 $\pm 0,44$ años) participaron en la estudio. Mientras que el protocolo sin masaje consistió en solo 15 minutos de jogging (NM), el protocolo con masaje deportivo consistió en 5 minutos de jogging y 10 minutos de masaje deportivo (SM). Los protocolos se aplicaron en dos períodos del día (mañana: 09.00 a 11.00, tarde: 16.00 a 18.00). Se ha informado que SM afecta positivamente la potencia máxima y la potencia media debido al rendimiento del salto vertical en comparación con el protocolo NM. Además, se determinó que el protocolo SM aplicado por la noche fue más efectivo que el protocolo SM aplicado por la mañana.

PALABRAS CLAVE: Variación diurna. Masaje desportivo. Salto vertical. Potencia anaeróbica. Potencia media.

\section{Introduction}

In sports with anaerobic content, coordination, agility, balance, speed and power are the most important components (CRESPO; MILLEY, 1998; ALTİNKÖK; ÖLÇÜCÜ, 2012). Various methods have been developed to estimate anaerobic power as a result of exercises. Maximum accumulated oxygen deficit (MAOD) (HILL; DAVEY; STEVENS, 2002; LIMAA, 2007), Wingate test (WAnT) (DOTAN; BAR-OR, 1983; BAR-OR, 1987; BENEKE et al., 2002), maximum anaerobic running test (MART) (NUMMELA et al., 1996), Margaria stair running test (NEDELJKOVIC et al., 2007), vertical jump tests (NUMMELA, et al., 1996) are some of these methods used to estimate this parameter. Especially in offensive and defensive situations in combat sports (ZANGELIDİS et al., 2012; LIMA et al., 2017) vertical jump has traditionally been used frequently to evaluate the power output of athletes and jump height has been accepted as an indicator of power output (MARKOVİC; JARİC, 2005; MARKOVIC; JARİC, 2007; YOUNG; CORMACK; CRİCHTON, 2011). Judo, known as a Japanese martial art, needs short, fast, maximum power and strength during the match (FRANCHINI et al., 2011; CHTOUROU et al., 2013). Therefore, in addition to mental concentration, physical coordination, strength and agility performances should be at a high level in judo (KYLE, 2011). Vertical jump tests were frequently used to determine whether the power performance of judokas was at the maximum level (MONTEIRO et al., 2011; LIMA et al., 2017). For example, as a result of the vertical jump tests, it was stated that judokas had important indicators of strength and speed (PANOUTSAKOPOULOS et al., 2016; LIMA et al., 2017; KONS et al., 2018). One of the factors in determining the anaerobic power indicators of athletes is to improve the current situation. For this reason, it has been 
determined that different protocols are applied to improve anaerobic capacity. For example, MacDougall et al. (1977) stated that increases in ATP and PC storage following resistance training after a 5-month resistance training program (8-10 reps, 3-5 sets of elbow extension) may be beneficial in performances such as sprinting (MACDOUGALL et al., 1977). In addition, improvements in anaerobic power occurred in individuals after a period of resistance training (SLADE et al., 2003; CHROMİK et al., 2004), an increase in anaerobic capacity after 4th session in the training program consisting of 16 electromyostimulation (EMS) training sessions (30 min per session) (MIYAMOTO et al., 2016). In addition to the training programs, one of the most important modalities that is thought to contribute to recovery and performance development is sports massage. Massage is applied rhythmically through pressure and stretching, defined as mechanical stimulation of tissues to aid acute preparation before performance (PRENTICE et al. 2004). It has also been widely used for therapeutic purposes in most cultures since past civilizations (CALLAGHAN, 1993; GOATS, 1994). Sports massage is used before exercise to improve exercise performance (ARROYOMORALES et al., 2011), to support the recovery of muscle performance and to reduce postexercise fatigue (OGAİ et al., 2008). It has been reported that sports massage is effective in reducing perceived lower extremity fatigue and muscle stiffness and in restoring total strength during cycling ergometry (OGAİ, et al., 2008). In addition, it was observed that massage improved WAnT performance of athletes after the Wingate anaerobic cycle test (WAnT) (MİCKLEWRIGHT et al., 2005). It has been reported that the friction massage technique is more effective in removing lactic acid after anaerobic running compared to the non-massage group (TASKIN; BUDAK; SANIOĞLU, 2020). It has been stated that daily variation is effective in many physiological and behavioral variables in sports performance, and different results have been observed on daily variation (DESCHENES, et al. 1998; REILLY; GARRETT, 1998; RACINAİS et al., 2005). Various mechanisms have been involved in achieving different results in daily variation on performance. Body temperature changes during the day were associated with physical performance differences observed in the afternoon compared to morning hours (KLİNE et al., 2006) and it was determined that the maximum short-term performances reached the lowest values in the morning and maximum in the afternoon (SEDLİAK et al., 2008; SOUİSSI et al., 2010). In addition, according to the results of the vertical jump tests, there is a $5-7 \%$ difference between the tests performed in the morning and evening (9:00 and 18:00) (BERNARD et al., 1997), while the highest isometric grip strength is found at 14:00. It was observed between 19:00 (REILLY et al., 2007). The existence of a daily performance variation was confirmed during only 1-3 first repetitions of 
exercise during repeated short-duration high-intensity activities (RACINAİS et al., 2005; HAMMOUDA, 2011; PULLINGER et al., 2018). In addition, during $5 \times 6$ second bicycle sprints with a recovery period of 24 seconds, peak power values were found to be significantly higher in the afternoon (17:00) than in the morning (7:00) (CHTOUROU et al., 2012).

Judo competitions are held in the morning and afternoon, and the athletes participating in the competition participate in several fighting competitions during the day. Therefore, it is important to investigate the studies that contribute to the daily performance changes of the athletes. Massage, which is widely used by athletes and thought to contribute to recovery performance, has different effects on performance improvement. In addition, it is observed that there are differences between the performance levels at different times of the day. From this point of view, it is seen that there is no study in the literature regarding the level of contribution of massage performed at different times of the day to performance development. This study was planned to determine the effects of massage on anaerobic performance and diurnal variation from morning to evening. The hypotheses of the study were determined to affect the vertical jump performance of the SM.

\section{Method}

\section{Participants}

Twelve male athletes between the ages of 18-25, who have been doing judo for at least 3 years, who exercise regularly for three days a week, participated in the study (age, 18.00土 2.17 years; height, $168 . \pm 3.15 \mathrm{~cm} ; 65 \pm 2,63 \mathrm{~kg}$; BMI 22.49 \pm .44$)$. The criteria for inclusion of judokas in the research are (a) having been practicing judo for at least 3 years; (b) not have a history of disability that would affect the result of the study; (c) ensure regular participation in the study; (d) was determined as following the researchers' commands throughout the study. All judokas were given the necessary information about the requirements and risks related to the study and signed an informed consent form stating that they voluntarily participated in the study. The judokas participating in the study were given instructions on sleep and nutrition before the study and were asked to get at least six hours of sleep until the study day and to maintain their normal sleep habits. During the study, the athletes were asked to maintain their usual physical activity and refrain from strenuous activity for 24 hours prior to the study. They were also prohibited from consuming any stimulants (eg caffeine) or depressants (eg alcohol) prior to the study. Before starting the study, necessary approval was obtained from 
the Malatya Inonu University Clinical Research Ethics Committee (Ethics Committee Protocol Number 2021/2616). Anaerobic performance measurements were taken from the judokas after different time periods of NM and SM (08.00-11.00, 16.00-19.00).

Figure 1 - Experimential flow diagram

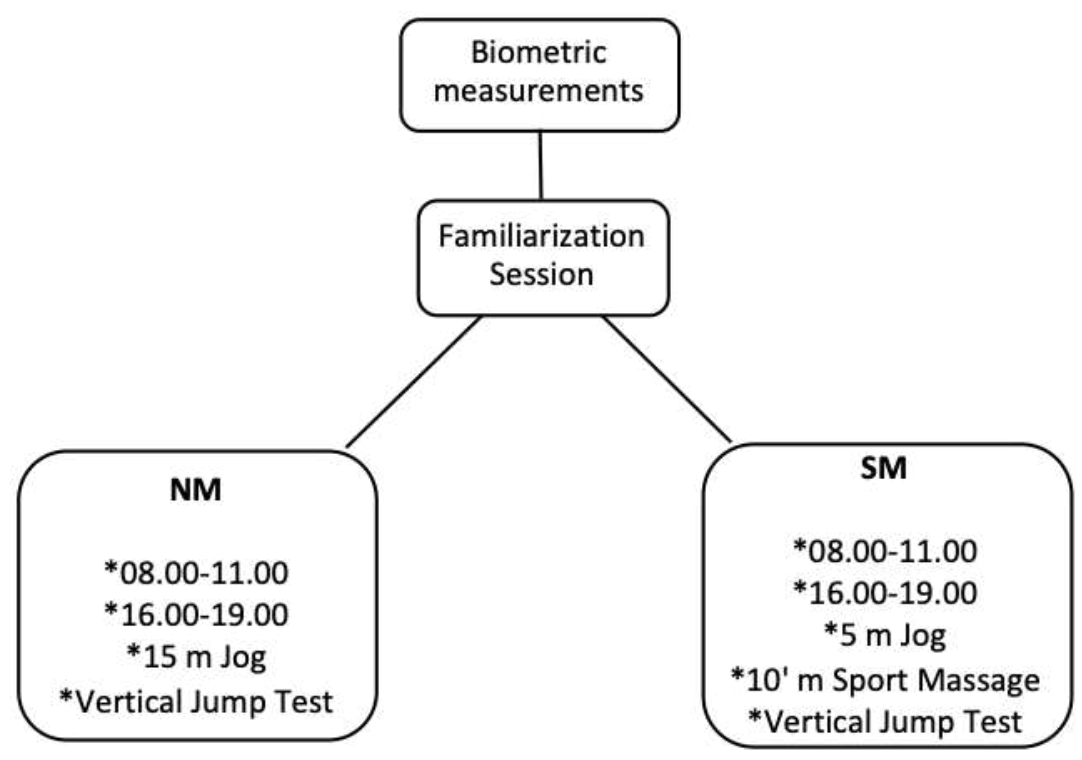

Source: Prepared by the authors

\section{Experimental Design of the Study}

This study consists of a single group of twelve judokas. There is no control group in the study. In the study, the NM protocol was divided into morning (08.00-11.00) and evening (16.00-19.00). In addition, the SM protocol was divided into (08.00-11.00) and evening (16.00-19.00). A time interval of 72 hours was reported between the two different protocols (FOX, 2012). To exclude a cumulative effect, twelve judokas were recruited into two different massage protocols in random order. During the familiarization session, the judokas were informed about the protocols (NM, SM) and measurement times (08.00-11.00 in the morning and 16.00-19.00 in the evening). NM protocol consisted of 15 minutes of jogging; SM protocol consisted of 5 minutes of jogging and 10 minutes of sports massage. After the protocols, vertical jump measurements were taken from judokas and the average and peak anaerobic power performances of the judokas were determined according to Johnson \& Bahomonde (1996) formula (JOHNSON; BAHAMONDE, 1996). This study continued for about 20 days with the familiarization session. Three attempts were made for the counter 
movement jump test (Smart Jump; Fusion Sport, Australia). The highest value of the three trials for each variable was used for analysis.

Table 1 - Formulas for Johnson and Bahamonde estimated peak power and power averages (JOHNSON; BAHAMONDE, 1996).

Peak power $(\mathbf{W})=78.5 \times \mathrm{VJ}(\mathrm{cm})+60.6 \times$ mass $(\mathrm{kg})-15.3 \times$ height $(\mathrm{cm})-1308$

Average power $(\mathbf{W})=41.4 \times \mathrm{VJ}(\mathrm{cm})+31.2 \mathrm{x}$ mass $(\mathrm{kg})-13.9 \times$ height $(\mathrm{cm})+431$

Source: Prepared by the authors

Sports Massage: After five minutes of jogging, the judokas were given 10-minute sports massage. Since judo competitions involve both upper and lower body muscle groups, massage treatments were applied to all body muscles for 10 minutes after the warm-up run (POCECCO et al., 2012). The subject groups were massaged in the direction of the heart and muscle fibers by using eufluorage, friction, petrissage, and pressing applications, which are among the sports massage applications (WEERAPONG; HUME; KOLT, 2005; AÇAK; ÖNCÜ, 2006; JELVÉUS, 2011). In order to ensure consistency between the massage treatments applied to different athletes, all judokas were massaged by the same masseur. Aromatic oils, which affect the effect of massage, were not used especially in massage application.

\section{Statistical analysis}

Since the number of volunteers participating in the study was less than 50 , the normality analyzes of the data were tested with the Shapiro Wilk's test. Paired Samples T-test was used to test the significance of the difference between the arithmetic means of two related groups. All statistical analyzes were performed with the IBM Statistics (SPSS, version 25.0, Armony, NY) package program. Data were expressed as mean \pm standard deviation $(\overline{\mathrm{x}} \pm \mathrm{ss})$ and significance level was accepted as $p<0.05$. 


\section{Results}

Figure 2 - NM and SM morning to evening vertical jump values

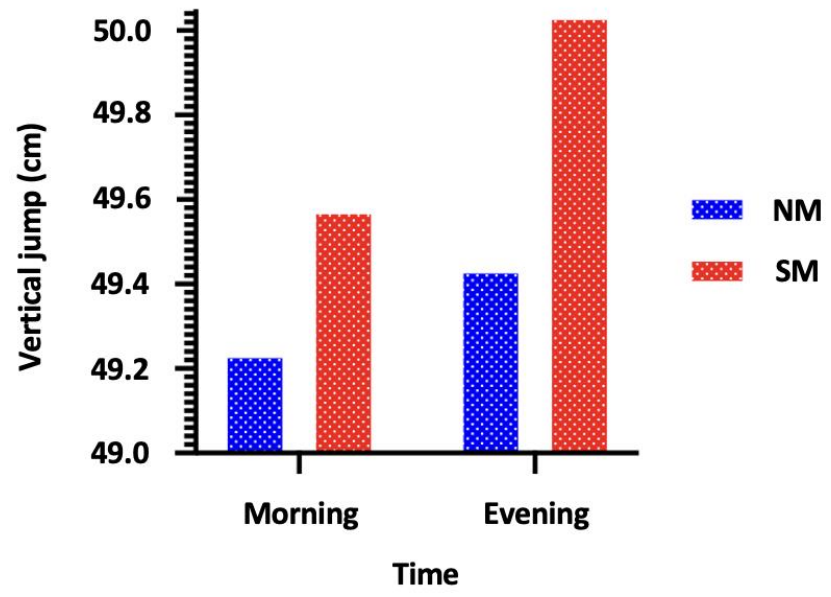

Source: Prepared by the authors

Figure 2 shows the comparison between NM and SM morning to evening vertical jump values. After NM (morning, 49.23 \pm 3.12 ; evening, 49.57 \pm 3.09 ) protocol, there was an increase in vertical jump values from morning to evening. After NM protocol, there was a statistically significant difference between the values of vertical jump from morning to evening ( $\mathrm{t}=-4,048 ; \mathrm{p}<, 002)$. After SM (morning, 49.43 \pm 2.83 ; evening, 50.03 \pm 2.86$)$ protocol, there was an increase in vertical jump values from morning to evening. After the SM protocol, there was a statistically significant difference between the values of vertical jump from morning to evening $(t=-4.681 ; \mathrm{p}<.001)$. However, when the protocols between NM and SM morning to evening vertical jump values were compared, it was determined that although there was a statistical difference, there was no statistical difference (NM and SM morning, $\mathrm{t}=$ 1.016; $\mathrm{p}<.330 ; \mathrm{NM}$ and $\mathrm{SM}$ evening, $\mathrm{t}=-1.794 ; \mathrm{p}<.098)$. 
Figure 3 - Average power values of NM and SM from morning to evening

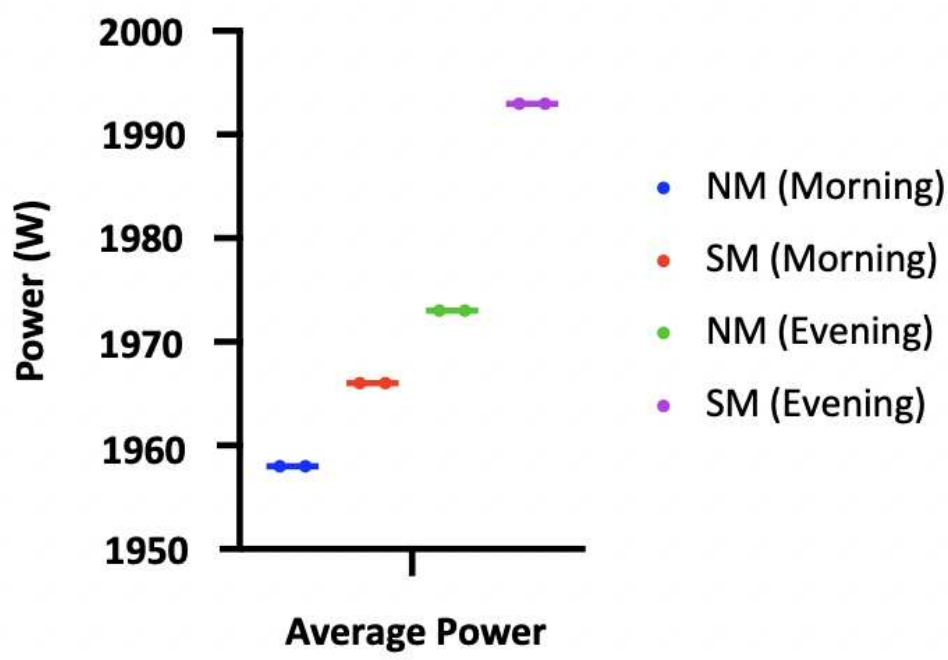

Source: Prepared by the authors

Figure 3 shows the comparison between NM and SM morning to evening average power values. After the NM (morning, 1957.69 \pm 42.21 ; evening, 1972.62 \pm 42.35 ) protocol, it was determined that there was an increase in the mean power values from morning to evening. After NM protocol, there was a statistically significant difference between the mean power values from morning to evening $(\mathrm{t}=-4.042 ; \mathrm{p}<.002)$. After SM (morning, 1966.15 \pm 38.49 ; evening, 1992.85 \pm 38.23 ) protocol, it was determined that there was an increase in the mean power values from morning to evening. After the SM protocol, there was a statistically significant difference between the mean power values from morning to evening $(\mathrm{t}=-4.646 ; \mathrm{p}<.001)$. However, when the protocols between NM and SM morning to evening mean power values were compared, it was determined that although there was a mathematical difference, there was no statistical difference (NM and SM morning, $\mathrm{t}=-1.019 ; \mathrm{p}<.328$; NM and SM evening, $\mathrm{t}=-1.788 ; \mathrm{p}<.099)$. 
Figure 4 - NM and SM peak power values from morning to evening

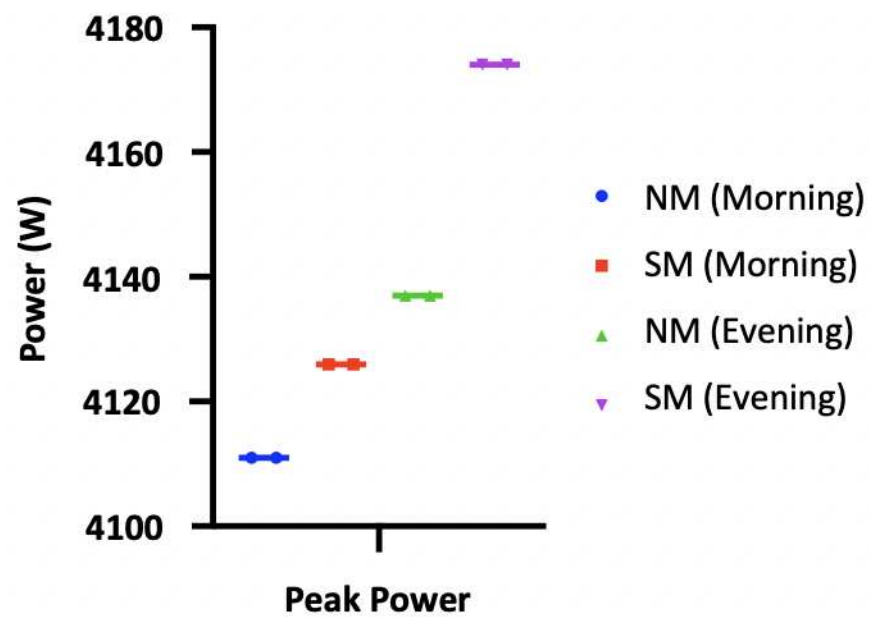

Source: Prepared by the authors

Figure 4 shows the comparison between NM and SM morning to evening peak power values. It was determined that there was an increase between morning to evening peak power values observed after NM (morning, 4110.85 \pm 82.69 ; evening, 4137.46 \pm 83.01 ) protocol. After NM protocol, there was a statistically significant difference between morning and evening peak power values $(\mathrm{t}=-4.070 ; \mathrm{p}<.002)$. It was determined that there was an increase between morning and evening peak power values observed after SM (morning, 4125.85 \pm 76.27 ; evening, 4173.77 \pm 75.58 ) protocol. After SM protocol, there was a statistically significant difference between morning and evening peak power values $(t=-4.697 ; p<0.001)$. However, when the protocols between NM and SM peak power values from morning to evening were compared, it was determined that although there was a mathematical difference, there was no statistical difference (NM and SM morning, $\mathrm{t}=-1.010 ; \mathrm{p}<.333$; $\mathrm{NM}$ and $\mathrm{SM}$ evening, $\mathrm{t}=-1.793$; $\mathrm{p}<.098)$.

\section{Discussion}

It is stated that the performances of the athletes during exercise or competition differ according to the time of exercise or competition. For this purpose, coaches or sports scientists are constantly working on the development of athlete performance. With the studies carried out, it is tried to determine the exercise protocols and time intervals in which athletes show the highest performance. It is thought that massage protocols applied before exercise or competition contribute to the performance development of athletes. However, the time intervals in which applied massage protocols contribute the most to performance development 
have not been determined yet. It is considered important to determine the most appropriate protocol that contributes to performance development, especially in sports branches such as judo that require anaerobic performance, studies examining the effects of massage exercises that provide performance improvement before exercise or competition may add originality to the literature for judo athletes. The aim of our study is to evaluate the effects of massage on anaerobic performance and diurnal variation from morning to evening. From our hypotheses, it was determined that SM had a positive effect on peak power and power averages depending on the vertical jump performance compared to the NM protocol, and SM protocol applied in the evening was more effective than the SM protocol applied in the morning. In addition, the hypothesis that SM application applied at different time intervals could produce different results on peak power and average power values was also confirmed.

As a result of the literature review, it is the first study to compare the effects of massage on anaerobic performance and diurnal variation from morning to evening. According to the results of the study, it was determined that SM applied to the judokas in the evening had a positive effect on acute performance.

This is the first study to examine the effect of sports massage applied to judoka on anaerobic performance and diurnal variation. However, the findings are consistent with studies with similar characteristics examining the effects of anaerobic performance and diurnal variation. Studies in the literature including well-trained judoka (CHTOUROU et al., 2013) and tennis players LÓPEZ-SAMANES et al., 2017) reported that evening performances were significantly higher than in the morning. Hill and Smith (1991) measured anaerobic power and capacity in the morning and evening hours with a modified version of the Wingate test. It has been found that peak and average power outputs in the evening hours are higher than in the morning hours (HİLL; SMITH, 1991). Reilly et al. (2007) reported a $10.7 \%$ performance decrease in the morning hours compared to the afternoon in the agility values applied using the dribbling test (REÍLLY et al., 2007). Racinais (2005) evaluated leg strength using the repeated sprint ability test and found that the strength in the first sprint was 4.7\% lower in the morning than in the afternoon (RACINAİS et al., 2005). Souissi et al. (2004) reported that during the Wingate test, the peak and mean power fluctuated ac cording to the time of day, reaching the lowest values in the morning $(7.6 \pm 0.8 \%)$ and peak values in the afternoon/evening $(11.3 \pm 1.1 \%)$ (SOUISSİ et al., 2004). Similarly, Chtourou et al. (2012) stated that during the Wingate test, peak power and mean power were higher in the evening $(3.1 \pm 3.6 \%)$ than in the morning $(2.9 \pm 3.5 \%)$ (CHTOUROU et al., 2012). In addition, it has been stated in studies that the maximum short-term performances are reached with the lowest 
values in the morning and maximum values in the afternoon (SEDLIAK et al., 2008; SOUİSSİ et al., 2010).

According to the findings, although it is consistent with studies with similar characteristics examining the effects of anaerobic performance and diurnal variation from morning to evening, it shows contradictory results with studies examining the effect of massage on performance. It has been stated that pre-performance massage has no effect on mood, but facilitates enhanced WAnT performance, and the relationship between massage and anaerobic performance remains unclear (MİCKLEWRIGHT et al., 2005). Kargarfard et al., (2016) consisted of 30 male bodybuilders who were separated from the massage and control group. At the end of the study, the control group observed worsening vertical jump performance at 48 and 72 hours (KARGARFARD et al., 2016). They also stated that the vertical jump performance of the massage group returned to the initial level at the 48th hour. It has been found that pre-exercise massage reduces muscle strength (WIKTORSSONMOLLER, et al., 1983) and has negative effects on vertical jump, speed and reaction time (ARABACI, 2008). The fact that the massage applied to increase sprint performance does not significantly benefit sprint performance (WALTERS, 2012), causes the effectiveness of precompetition massage applications to be discussed (MORAN; HAUTH; RABENA, 2018). It has been reported that massage does not prevent speed performance, but massage can provide a psychological benefit for athletes (PEÑA et al., 2014). Similarly, it has been found that sports massage is not harmful for flexibility or performance but can be used as a part of warming up (RİCHMAN; TYO; NİCKS, 2019). Considering individual factors, accompanied by scientific evidence, athletes should continue to use massage if it works (GWYNEE, 2012).

\section{Conclusion}

According to the results found in this study, it was determined that SM positively affected the peak power and mean power depending on the vertical jump performance compared to the NM protocol. In addition, it was determined that the SM protocol applied in the evening was more effective than the SM protocol applied in the morning. When evaluated from this point of view, sports scientists, coaches and athletes can contribute to performance increase if they include SM practice in their work. However, more in-depth and detailed studies are needed in order to obtain more precise results and to explain the contribution of SM application to performance. It is thought that determining the physiological mechanism of SM application will lead to future scientific studies. 


\section{REFERENCES}

AÇAK, M.; ÖNCÜ, E. H. Adım adım masaj öğretimi. Malatya: Boyut Yayın, 2006.

ALTİNKÖK, M.; ÖLÇÜCÜ B. The examination on postural control and agility performance of 10 year old tennis players before the competition. Selçuk University Journal of Physical Education and Sport Science, v. 14, n. 2, p. 273-276, 2012.

ARABACI, R. Acute effects of pre-event lower limb massage on explosive and high speed motor capacities and flexibility. J Sport Sci Med, v. 7, p. 549-555, 2008.

ARROYO-MORALES, M. et al. Psychophysiological effects of preperformance massage before isokinetic exercise. Journal of Strength \& Conditioning Research, v. 25, n. 2, p. 481-488, 2011. DOI: https://doi.org/10.1519/JSC.0b013e3181e83a4

BAR-OR, O. The Wingate anaerobic test: An update on methodology, reliability and validity. Sports Med, v. 4, p. 381-394, 1987.

BENEKE, R. et al. How anaerobic is the Wingate anaerobic test for humans. Eur J Appl Physiol, v. 87, p. 388-392, 2002.

BERNARD, T. et al. Time-of-day effects in maximal anaerobic leg exercise. European Journal of Applied Physiology and Occupational Physiology, v. 77, n. 1, p. 133-138, 1997.

CALLAGHAN, M. J. The role of massage in the management of the athlete: a review. Br $\mathbf{J}$ Sports Med, v. 27, p. 28-33, 1993. DOI: http://dx.doi.org/10.1136/bjsm.27.1.28

CHROMIAK, J. A. et al. Effect of a 10-week strength training program and recovery drink on body composition, muscular strength and endurance, and anaerobic power and capacity.

Nutrition, v. 20, p. 420-427, 2004. DOI: https://doi.org/10.1016/j.nut.2004.01.005

CHTOUROU, H. et al. The effect of time-of-day and judo match on short-term maximal performances in judokas. Biological Rhythm Research, v. 44, n. 5, p. 797-806, 2013. DOI: https://doi.org/10.1080/09291016.2012.756269

CHTOUROU, H. et al. The effect of training at the same time of day and tapering period on the diurnal variation of short exercise performances. J. Strength Cond. Res, v. 26, p. 697708, 2012. DOI: https://doi.org/10.1519/JSC.0b013e3182281c87

CRESPO, M.; MILLEY, D. Advanced coaches manual, Bahamas Canada. West Bay Street Nassau, v. 1, p. 149, 1998.

DESCHENES, M. R. et al. Chronobiological effects on exercise performance and selected physiological responses. European Journal of Applied Physiology and Occupational Physiology, v. 77, n. 3, p. 249-256, 1998.

DOTAN, R.; BAR-OR, O. Load optimization for the Wingate Anaerobic Test. Eur J Appl Physiol, v. 51, p. 409-417, 1983. 
FOX, B. F. Beden Eğitimi ve Sporun Fizyolojik Temelleri. Trans. Mesut Cerit. Ankara: Spor Yayınevi; 2012.

FRANCHINI, E. et al. Physiological profiles of elite judo athletes. Sports Med, v. 41, p. $147-166,2011$.

GOATS, G. C. Massage-The scientific basis of an ancient art: Part 1. The techniques. Br J Sports Med, v. 28, p. 149-152, 1994. DOI: http://dx.doi.org/10.1136/bjsm.28.3.153

GWYNEE, S. The effects of pre-event sports massage on psychological mood state and performance. Cardiff: University of Wales Institute Cardiff; 2012.

HAMMOUDA, O. et al. Diurnal variations of plasma homocysteine, total antioxidant status, and biological markers of muscle injury during repeated sprint: effect on performance and muscle fatigue-a pilot study. Chronobiol. Int, v. 28, p. 958-967, 2011. DOI:

http://dx.doi.org/10.3109/07420528.2011.613683

HILL, D. W.; DAVEY, K. M.; STEVENS, E. C. Maximal accumulated O2 deficit in running and cycling. Can J Appl Physiol, v. 27, p. 463-478, 2002. DOI: https://doi.org/10.1139/h02025

HILL, D. W.; SMITH, J. C. Circadian rhythm in anaerobic power and capacity. Canadian Journal of Sport Sciences $=$ Journal Canadien des Sciences du Sport, v. 16, n. 1, p. 30-32, 1991.

JELVÉUS, A. Integrated sports massage therapy a comprehensive handbook. Elsevier Ltd., 2011.

JOHNSON, D. L.; BAHAMONDE, R. Power output estimate in university athletes. Journal of strength and Conditioning Research, v. 10, p. 161-166, 1996.

KARGARFARD, M. et al. Efficacy of massage on muscle soreness, perceived recovery, physiological restoration and physical performance in male body builders. J Sports Sci, v. 34, p. 1-7, 2016. DOI: https://doi.org/10.1080/02640414.2015.1081264

KLİNE, C. E. et al. Circadian variation in swim performance. Journal of Applied Physiology, v. 102, n. 2, p. 641-649, 2007. DOI: https://doi.org/10.1152/japplphysiol.00910.2006

KONS, R. L. et al. Is vertical jump height an indicator of athletes' power output in different sport modalities? The Journal of Strength \& Conditioning Research, v. 32, n. 3, p. 708715, 2018. DOI: 10.1519/JSC.0000000000001817

KYLE, L. A. A post exercise dynamic stretching manual for judo instructors. Sacramento: California State University; 2011.

LIMA, K. R. et al. Vertical jump performance in judo and Brazilian jiu-jitsu athletes: an approach with different training levels. Ido Movement for Culture. Journal of Martial Arts Anthropology, v. 17, n. 4, p. 25-31, 2017. 
LIMA, M. C. S. Standardization of the tethered running in sprint athletes: Analysis of relation between power and performance in running. Rio Claro: Sao Paulo State University, 2007.

LÓPEZ-SAMANES, Á. et al. Circadian rhythm effect on physical tennis performance in trained male players. Journal of Sports Sciences, v. 35, n. 21, p. 2121-2128, 2017. DOI: $10.1080 / 02640414.2016 .1258481$

MACDOUGALL, J. D. et al. Biochemical adaptation of human skeletal muscle to heavy resistance training and immobilization. J Appl Physiol, v. 43, p. 700-703,1977. DOI: https://doi.org/10.1152/jappl.1977.43.4.700

MARKOVIC, G.; JARİC S. Is vertical jump height a body size independent measure of power output? J Sports Sci, v. 25, p. 1355-1363, 2007.

MARKOVIC, G.; JARİC, S. Scaling of power output to body size: The effect of stretchshortening cycle. Eur J Appl Physiol, v. 95, p. 11-19, 2005.

MICKLEWRİGHT, D. et al. Mood state response to massage and subsequent exercise performance. The Sport Psychologist, v. 19, n. 3, p. 234-250, 2005. DOI:

https://doi.org/10.1123/tsp.19.3.234

MIYAMOTO, T. et al. Low-intensity electrical muscle stimulation induces significant increases in muscle strength and cardiorespiratory fitness. Eur J Sport Sci, v. 16, p. 1104 1110, 2016. DOI: https://doi.org/10.1080/17461391.2016.1151944

MONTEIRO, LF. et al. Plyometric muscular action tests in judo-and non-judo athletes. Isokinetics and Exercise Science, v. 19, n. 4, p. 287-293, 2011. DOI: https://doi.org/10.3233/IES-2011-0429.

MORAN, R. N.; HAUTH, J. M.; RABENA, R. The effect of massage on acceleration and sprint performance in track \& field athletes. Complementary Therapies in Clinical Practice, v. 30, p. 1-5, 2018. DOI: https://doi.org/10.1016/j.ctcp.2017.10.010

NEDELJKOVIC, A. et al. Evaluation of Margaria staircase test: the effect of body size. Eur J Appl Physiol, v. 100, p. 115-120, 2007.

NUMMELA, A. et al. Reliability and validity of the maximal anaerobic running test. Int $\mathbf{J}$ Sports Med, v. 17, p. 97-102, 1996.

OGAİ, R. et al. Effects of petrissage massage on fatigue and exercise performance following intensive cycle pedalling. British Journal of Sports Medicine, v. 42, n. 10, p. 834-838, 2008. DOI: http://dx.doi.org/10.1136/bjsm.2007.044396

PANOUTSAKOPOULOS, V. et al. Vertıcal jump performance and power assessement of greek junior national level judo athletes. In: FIS COMMUNICATIONS INTERNATIONAL SCIENTIFIC CONFERENCE, 19., Niš, 2016. Proceedings [...]. Niš, Serbia, 2016.

PEÑA, I. M. et al. Effects of pre-event massage on speed in collegiate sprinters. California: California Satate University Fullerton; 2014. 
POCECCO, E. et al. Specific exercise testing in judo athletes. Arch. Budo, v. 8, p. 133-139, 2012. DOI: http://dx.doi.org/10.12659/AOB.883246

PRENTICE, W. E. et al. Rehabilitation techniques for sports medicine and athletic training. 4. ed. New York: McGraw Hill, 2004.

PULLINGER, S. A. et al. Diurnal variation in repeated sprint performance cannot be offset when rectal and muscle temperatures are at optimal levels $\left(38.5^{\circ} \mathrm{C}\right)$. Chronobiol. Int, v. 35, p. 1054-1065, 2018. DOI: http://dx.doi.org/10.1080/07420528.2018.1454938

RACINAIIS, S. et al. Morning versus evening power output and repeated-sprint ability. Chronobiol Int, v. 22, p. 1029-1039, 2005. DOI: https://doi.org/10.1080/07420520500397918

REİLLY, T. et al. Diurnal variation in temperature, mental and physical performance, and tasks specifically related to football (soccer). Chronobiology International, v. 24, n. 3, p. 507-519, 2007. DOI: https://doi.org/10.1080/07420520701420709

REILLY, T.; GARRETT, R. Investigation of diurnal variation in sustained exercise performance. Ergonomics, v. 41, p. 1085-1094, 1998. DOI:

https://doi.org/10.1080/001401398186397

RİCHMAN, E. D.; TYO, B. M.; NİCKS, C. R. Combined effects of self-myofascial release and dynamic stretching on range of motion, jump, sprint, and agility performance. The Journal of Strength \& Conditioning Research, v. 33, n. 7, p. 1795-1803, 2019. DOI: http://dx.doi.org/10.1519/JSC.0000000000002676

SEDLIAK, M. et al. Effect of time-of-day-specific strength training on maximum strength and EMG activity of the leg extensors in men. J Sports Sci, v. 26, p. 1005-1014, 2008. DOI: https://doi.org/10.1080/02640410801930150

SLADE, J. M. et al. Anaerobic power and physical function in strength-trained and nonstrength-trained older adults. J Gerontol Biol Sci Med Sci, v. 57, p. 168-172, 2002. DOI: https://doi.org/10.1093/gerona/57.3.M168

SOUİSSI, N. et al. Circadian rhythms in two types of anaerobic cycle leg exercise: forcevelocity and 30-s Wingate tests. Int J Sports Med, v. 25, p. 14-19, 2004. DOI:

http://dx.doi.org/10.1055/s-2003-45226

SOUISSI, N. et al. Diurnal variation in Wingate test performances: Influence of active warmup. Chronobiol Int, v. 27, p. 640-652, 2010. DOI:

https://doi.org/10.3109/07420528.2010.483157

TASKIN, M.; BUDAK, H.; SANIOĞLU, A. The Effect of Selected Massage Manipulations on Lactic Acid Elimination After Anaerobic Running. International Journal of Applied Exercise Physiology, v. 9, n. 1, p. 133-138, 2020.

WALTERS, D. The effects of pre-event massage on sprint performance in females. Cardiff: University of Wales Institute Cardiff; 2012. 
WEERAPONG, P.; HUME, P. A.; KOLT, G. S. The mechanisms of massage and effects on performance, muscle recovery and injury prevention. Sports Medicine, v. 35, n. 3, p. 235 $256,2005$.

WİKTORSSON-MOLLER, M. et al. Effects of warming up, massage, and stretching on range of motion and muscle strength in the lower extremity. Am J Sports Med, v. 11, p. 249252, 1983. DOI: https://doi.org/10.1177/036354658301100412

YOUNG, W.; CORMACK, S.; CRİCHTON M. Which jump variables should be used to assess explosive leg muscle function? Int J Sports Physiol Perform, v. 6, p. 51-57, 2011.

ZANGELIDİS, G. et al. Differences in vertical jumping performance between untrained males and advanced Greek judokas. ARCH BUDO, v. 8, n. 2, p. 87-90, 2012.

\section{How to reference this article}

BAYER, R.; EKEN, Ö. Some anaerobic performance variations from morning to evening: massage affects performance and diurnal variation. Revista online de Política e Gestão Educacional, Araraquara, v. 25, n. 3, p. 2459-2474, set./dez. 2021. e-ISSN: 1519-9029. DOI: https://doi.org/10.22633/rpge.v25i2.15914

Submitted: 07/09/2021

Required revisions: 10/10/2021

Approved: 07/11/2021

Published: 08/12/2021 